\title{
How Bacteria Change after Exposure to Silver Nanoformulations: Analysis of the Genome and Outer Membrane Proteome
}

\author{
Anna Kędziora ${ }^{1, *(\mathbb{D})}$, Mateusz Speruda ${ }^{1}$, Maciej Wernecki ${ }^{1}\left(\mathbb{D}\right.$, Bartłomiej Dudek ${ }^{1}$, Katarzyna Kapczynska ${ }^{2} \mathbb{D}^{\text {, }}$ \\ Eva Krzyżewska ${ }^{2}$ (D) Jacek Rybka ${ }^{2}$ and Gabriela Bugla-Płoskońska ${ }^{1, *(\mathbb{D}}$
}

1 Department of Microbiology, Faculty of Biological Sciences, University of Wroclaw, 51-148 Wroclaw, Poland; mateusz.speruda@uwr.edu.pl (M.S.); maciej.wernecki@uwr.edu.pl (M.W.);

bartlomiej.dudek@uwr.edu.pl (B.D.)

2 Department of Immunology of Infectious Diseases, Hirszfeld Institute of Immunology and Experimental Therapy, Polish Academy of Sciences, 53-114 Wroclaw, Poland; katarzyna.kapczynska@hirszfeld.pl (K.K.); eva.krzyzewska@hirszfeld.pl (E.K.); jacek.rybka@hirszfeld.pl (J.R.)

* Correspondence: anna.kedziora@uwr.edu.pl (A.K.); gabriela.bugla-ploskonska@uwr.edu.pl (G.B.-P.); Tel.: +487-1375-6323 (A.K.)

check for updates

Citation: Kẹdziora, A.; Speruda, M.; Wernecki, M.; Dudek, B.; Kapczynska, K.; Krzyżewska, E.; Rybka, J.; Bugla-Płoskońska, G. How Bacteria Change after Exposure to Silver Nanoformulations: Analysis of the Genome and Outer Membrane Proteome. Pathogens 2021, 10, 817 https://doi.org/10.3390/ pathogens10070817

Academic Editor: Iain Lamont

Received: 19 April 2021

Accepted: 24 June 2021

Published: 29 June 2021

Publisher's Note: MDPI stays neutral with regard to jurisdictional claims in published maps and institutional affiliations.

Copyright: (c) 2021 by the authors. Licensee MDPI, Basel, Switzerland. This article is an open access article distributed under the terms and conditions of the Creative Commons Attribution (CC BY) license (https:// creativecommons.org/licenses/by/ $4.0 /)$.
Abstract: Objective: the main purpose of this work was to compare the genetic and phenotypic changes of E. coli treated with silver nanoformulations (E. coli BW25113 wt, E. coli BW25113 AgR, E. coli J53, E. coli ATCC 11229 wt, E. coli ATCC 11229 var. S2 and E. coli ATCC 11229 var. S7). Silver, as the metal with promising antibacterial properties, is currently widely used in medicine and the biomedical industry, in both ionic and nanoparticles forms. Silver nanoformulations are usually considered as one type of antibacterial agent, but their physical and chemical properties determine the way of interactions with the bacterial cell, the mode of action, and the bacterial cell response to silver. Methods: the changes in the bacterial genome, resulting from the treatment of bacteria with various silver nanoformulations, were verified by analyzing of genes (selected with mutfunc) and their conservative and non-conservative mutations selected with BLOSUM62. The phenotype was verified using an outer membrane proteome analysis (OMP isolation, 2-DE electrophoresis, and MS protein identification). Results: the variety of genetic and phenotypic changes in E. coli strains depends on the type of silver used for bacteria treatment. The most changes were identified in E. coli ATCC 11229 treated with silver nanoformulation signed as S2 (E. coli ATCC 11229 var. S2). We pinpointed 39 genes encoding proteins located in the outer membrane, 40 genes of their regulators, and 22 genes related to other outer membrane structures, such as flagellum, fimbria, lipopolysaccharide (LPS), or exopolysaccharide in this strain. Optical density of OmpC protein in E. coli electropherograms decreased after exposure to silver nanoformulation S7 (noticed in E. coli ATCC 11229 var. S7), and increased after treatment with the other silver nanoformulations (SNF) marked as S2 (noticed in E. coli ATCC 11229 var. S2). Increase of FliC protein optical density was identified in turn after Ag+ treatment (noticed in E.coli AgR). Conclusion: the results show that silver nanoformulations (SNF) exerts a selective pressure on bacteria causing both conservative and non-conservative mutations. The proteomic approach revealed that the levels of some proteins have changed after treatment with appropriate SNF.

Keywords: bacteria; pathogens; Escherichia coli; genome analysis; mutations; outer membrane proteins; OMP; silver nanoformulations; SNF

\section{Introduction}

Since ancient times, silver has been known for its antiseptic properties. In the past, it was used as either silver ions or metallic silver. The development of nanotechnology has brought about new possibilities of using the antimicrobial potential of this metal. Among 
numerous metals with antibacterial properties, silver is in the spotlight of nanotechnologists due to its promising possibilities of use, both in and outside of the clinic. Over the last years, a significant increase in the production of silver nanomaterials has been observed, towards different purposes and with various methods being used, which is connected with a high diversity of silver nanomaterials in terms of size, shape, surface charge, and composition. The physical and chemical properties, frequently resulting from the type of synthesis, determine the interaction with bacterial cells, the mode of action, and bacteria's cell response to silver and other antibacterial agents (such as antibiotics and biocides) [1-3] The proposed mode of action of silver on bacterial cells has been previously described [2,4]. Direct interactions with bacterial cell structures and a physical impact on the cell envelope (outer membrane, peptidoglycan, or cell membrane) are the basic methods of cell disruption by forming gaps in the cell membrane or the inhibition of biochemical pathways. One of the proposed mechanisms is the uptake of silver into the cell by outer membrane proteins (OMP), such as OmpC and/or OmpF. Then, Ag atoms can interact with internal biomolecules, such as proteins and nucleic acids (DNA or RNA) [5-8]. Randall et al. [8] have confirmed that a bacterial cell deprived of OmpC and $\mathrm{OmpF}$ becomes more resistant to silver ions. A most important mode of action of silver is production of reactive oxygen species (ROS) that destroy cell components causing rearrangement in the cell envelope and changes in the biochemical pathways. A separate type of interaction with a bacterial cell is the intercalation with the genophore resulting in the inhibition of cell division or introduction of changes to the genetic material $[2,5,8]$. The substantial changes in the sensitivity of some bacterial strains to particular silver nanoformulations (SNF), and some antibiotics after a long-term treatment with SNF, as the effect of adaptation of the bacteria cell to the environmental stress or mutational changes, have been observed [1]. There are a number of papers speculating about and confirming the direct cytotoxicity of silver nanoparticles [4,5,8-10], but the genetic basis for the changes still remains unconfirmed. For a deeper explanation changes in the genes encoding OMP, flagella, fimbria, lipopolysaccharide (LPS), and exopolysaccharide by assigning the BLOSUM62 score [11,12], and based on an analysis of the mutfunc mutation database [13], has been showed. To our knowledge, this is the first publication where such a detailed analysis of the genome after bacteria treatment with selected SNF is shown. The E. coli cell phenotype using the outer membrane proteome analysis has also been included.

\section{Results}

\subsection{Genome Analysis}

Genes encoding outer membrane proteins carrying conservative and non-conservative mutations in E. coli ATCC 11229 var. S2, obtained using NGS genetic analysis, and grouped according to their involvement in molecular functions are listed in Table 1. They are related to transmembrane transport (channels, siderophore transporter and others), peptidoglycan (penicillin-binding protein activator, Braun's lipoprotein, membrane-bound lysozyme inhibitor, membrane-bound lytic murein transglycosylase B and murein hydrolase activator), lipids, intermembrane phospholipid transport system lipoprotein and metalloprotease) and others (outer membrane protein assembly factors, cellulose synthase operon protein $C$, bacteriophage adsorption protein A, poly-beta-1;6-N-acetyl-D-glucosamine $\mathrm{N}$-deacetylase, outer membrane lipoprotein, trans-aconitate 2-methyltransferase). Among $145 \mathrm{E}$. coli genes encoding outer membrane associated proteins, we have detected 39 genes with a total of 94 missense mutations, among which 26 were non-conservative mutations (BLOSUM62 criterion) and 7 mutations were selected by mutfunc as impactful (altered amino acids were present in the conservative region of the protein or alterations could potentially destabilize the protein). All the proteins, along with the list of conservative and non-conservative mutations, are summarized in Supplementary Materials Table S1. Products of these selected genes are responsible for the bacterial cell structure, transport, secretion, adhesion, and adsorption. Among the OMP, the following porins: $\mathrm{OmpC}, \mathrm{OmpF}, \mathrm{OmpG}$, and $\mathrm{OmpN}$ were pinpointed with conservative or non-conservative mutations (Supplementary Materials 
Table S1). The genes encoding proteins, which are related to OM and other outer membrane structures, such as flagellum, fimbria, LPS, and exopolysaccharide, were analyzed in a different way and the genes selected with mutfunc together with the list of conservative mutations detected with BLOSUM62 are summarized in Supplementary Materials Table S2, in total, 22 genes. Selected genes are mainly responsible for the structure of cellular flagellum, transport, oxidation stress, and respiratory cell. Moreover, regulators of genes identified in Supplementary Materials Tables S1 and S2 were pinpointed (40 genes listed in Supplementary Materials Table S3), in the list of conservative and non-conservative mutations. High number of mutations were identified in this case. Impactful mutations selected with mutfunc and accompanied by predicted effects of mutations for proteins were pinpointed in some transmembrane transporter activity fimD, ompN, yehB, fhuE, and $p g a A$, and others, such as yceB (uncharacterized lipoprotein).

Table 1. Genes encoding outer membrane proteins carrying mutations, grouped according to their involvement in molecular functions.

\begin{tabular}{|c|c|c|c|c|c|}
\hline \multicolumn{2}{|c|}{$\begin{array}{l}\text { Function of the Gene } \\
\text { Product }\end{array}$} & \multirow{2}{*}{$\begin{array}{l}\text { Gene } \\
\text { cusC }\end{array}$} & Product Description & Mutations & \multirow[t]{2}{*}{ Predicted Effects } \\
\hline \multirow{18}{*}{ 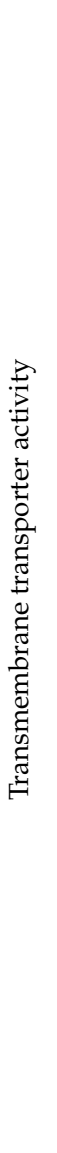 } & \multirow{10}{*}{ Channel } & & Cation efflux system protein CusC & Thr81Ala, Asn117Asp, Thr118Ser & \\
\hline & & fimD & Outer membrane usher protein & $\begin{array}{l}\text { Ser397Thr, Ile401Val, Gly403Ala, } \\
\text { Glu410Lys }\end{array}$ & $\begin{array}{l}\text { Alteration in a conserved } \\
\text { region, destabilizing } \\
\text { mutation }\end{array}$ \\
\hline & & отрС & Outer membrane porin $C$ & Ile306Val Thr305Val & - \\
\hline & & ompF & Outer membrane porin $\mathrm{F}$ & Asp48Gly, Val51Glu, Lys60Met, & - \\
\hline & & ompG & Outer membrane porin $\mathrm{G}$ & Ala67Ser & - \\
\hline & & $o m p N$ & Outer membrane porin $\mathrm{N}$ & Lys90Thr & Destabilizing mutation \\
\hline & & ts $x$ & $\begin{array}{l}\text { Nucleoside-specific } \\
\text { channel-forming protein }\end{array}$ & Ile53Leu & - \\
\hline & & uidC & Membrane-associated protein & Asn285Ile & - \\
\hline & & yehB & Outer membrane usher protein & Thr377Ser, Gln540His, Ile699Val & $\begin{array}{l}\text { Alteration in a conserved } \\
\text { region }\end{array}$ \\
\hline & & $y f a L$ & Probable autotransporter & $\begin{array}{l}\text { Thr879Ala, Pro920Pro, Pro921Thr, } \\
\text { Ser922Pro, Thr919Asn, Ser1091Asn } \\
\text { Glu1098Asp Thr1101Val }\end{array}$ & 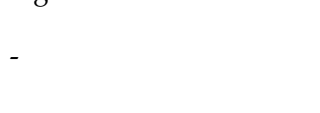 \\
\hline & \multirow{6}{*}{$\begin{array}{l}\text { Siderophore } \\
\text { transporter }\end{array}$} & $\operatorname{cir} A$ & Colicin I receptor & $\begin{array}{l}\text { Ile174Val } \\
\text { Ile56Phe Val350Leu Ile397Val }\end{array}$ & - \\
\hline & & $f e c A$ & $\mathrm{Fe}(3+)$ dicitrate transport protein & $\begin{array}{l}\text { Gly600Asp, Val605Ile, Leu651Phe, } \\
\text { Ser684Ala, Met693Ile }\end{array}$ & - \\
\hline & & fepA & Ferrienterobactin receptor & Thr356Ala & - \\
\hline & & fhuA & $\begin{array}{l}\text { Ferrichrome outer membrane } \\
\text { transporter/phage receptor } \\
\text { Outer-membrane receptor for }\end{array}$ & Ser110Ala & - \\
\hline & & fhuE & $\begin{array}{l}\text { Fe(III)-coprogen; } \\
\text { Fe(III)-ferrioxamine B and } \\
\text { Fe(III)-rhodotorulic acid }\end{array}$ & Ser61Asn & destabilizing mutation \\
\hline & & fiu & Catecholate siderophore receptor & Thr493Ala & - \\
\hline & & $g s p D$ & $\begin{array}{l}\text { Putative type II secretion system } \\
\text { protein D }\end{array}$ & Gln617Leu, Val627Ile & - \\
\hline & Others & $p g a A$ & $\begin{array}{l}\text { Poly-beta-1;6-N-acetyl-D- } \\
\text { glucosamine (PGA) export } \\
\text { protein }\end{array}$ & $\begin{array}{l}\text { Gln11Lys, Ile18Leu, Val26Ala, } \\
\text { Ile87Val, Ser90Arg, Ile106Val, } \\
\text { Pro129Ser, Thr150Ser, Pro451His, } \\
\text { Phe599Val }\end{array}$ & $\begin{array}{l}\text { Alteration in conserved } \\
\text { regions }\end{array}$ \\
\hline \multirow{6}{*}{ 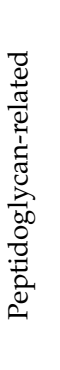 } & & $\operatorname{lpo} A$ & $\begin{array}{l}\text { Penicillin-binding protein } \\
\text { activator }\end{array}$ & Ala96Thr, Val106Ala, Ala292Val & - \\
\hline & & $\operatorname{lpoB}$ & $\begin{array}{l}\text { Penicillin-binding protein } \\
\text { activator }\end{array}$ & Pro71Leu & - \\
\hline & & $l p p$ & $\begin{array}{l}\text { Major outer membrane } \\
\text { lipoprotein (Braun lipoprotein) }\end{array}$ & Val26Ile & - \\
\hline & & mliC & $\begin{array}{l}\text { Membrane-bound lysozyme } \\
\text { inhibitor of C-type lysozyme }\end{array}$ & His25Arg, Ala29Asp & - \\
\hline & & mltB & $\begin{array}{l}\text { Membrane-bound lytic murein } \\
\text { transglycosylase B }\end{array}$ & Val49Met, Asp64Glu, Lys324Arg & - \\
\hline & & $n l p D$ & Murein hydrolase activator & Ala228Thr & - \\
\hline
\end{tabular}


Table 1. Cont.

\begin{tabular}{|c|c|c|c|c|c|}
\hline \multicolumn{2}{|c|}{$\begin{array}{l}\text { Function of the Gene } \\
\text { Product }\end{array}$} & \multirow{2}{*}{$\begin{array}{l}\text { Gene } \\
b l c\end{array}$} & \multirow{2}{*}{$\begin{array}{c}\text { Product Description } \\
\text { Outer membrane lipoprotein }\end{array}$} & Mutations & \multirow[t]{2}{*}{ Predicted Effects } \\
\hline $\bar{d}$ & & & & Gly84Glu & \\
\hline 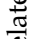 & & lolB & Outer membrane lipoprotein & Ala115Ser & - \\
\hline 常 & & $m l a A$ & $\begin{array}{l}\text { Intermembrane phospholipid } \\
\text { transport system lipoprotein }\end{array}$ & Gly168Ser & - \\
\hline ?्: & & $y c a L$ & Metalloprotease & Ser158Arg & - \\
\hline \multirow{10}{*}{ 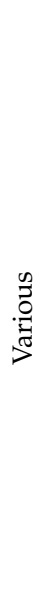 } & & bamB & $\begin{array}{l}\text { Outer membrane protein } \\
\text { assembly factor }\end{array}$ & Ser96Asn, Ser335Gly & - \\
\hline & Bam & bam C & $\begin{array}{l}\text { Outer membrane protein } \\
\text { assembly factor }\end{array}$ & Asp287Glu, Gln289His & - \\
\hline & \multirow{8}{*}{ Others } & $b c s C$ & $\begin{array}{l}\text { Cellulose synthase operon protein } \\
\text { C }\end{array}$ & $\begin{array}{l}\text { Val65Ile, Pro110Ser, Ala558Gly, } \\
\text { Ala775Thr }\end{array}$ & - \\
\hline & & $n f r A$ & $\begin{array}{l}\text { Bacteriophage adsorption protein } \\
\text { A }\end{array}$ & Ala98Asp, Ala115Asp, Ile784Leu & - \\
\hline & & $\operatorname{pg} a B$ & $\begin{array}{l}\text { Poly-beta-1;6-N-acetyl-D- } \\
\text { glucosamine N-deacetylase (PGA } \\
\text { N-deacetylase) }\end{array}$ & Leu575Met & - \\
\hline & & $\operatorname{sly} B$ & Outer membrane lipoprotein & Val78Ile & - \\
\hline & & tam & $\begin{array}{l}\text { Trans-aconitate } \\
\text { 2-methyltransferase }\end{array}$ & $\begin{array}{l}\text { Asn121Ser, Gln123Leu, Ser158Pro, } \\
\text { Ile162Val, Ala210Thr Leu216His }\end{array}$ & - \\
\hline & & yajI & Uncharacterized lipoprotein & Glu164Asp, Asp167Gly & - \\
\hline & & $y c e B$ & Uncharacterized lipoprotein & Glu126Gly & $\begin{array}{l}\text { Alteration in a conserved } \\
\text { region }\end{array}$ \\
\hline & & yfer & Uncharacterized protein & Gly142Ser, Arg167Ser & - \\
\hline
\end{tabular}

Non-conservative mutations selected with BLOSUM62 criterion are italicized. Impactful mutations selected with mutfunc are marked in bold and accompanied by predicted effects of mutations for proteins.

\subsection{Proteome Analysis}

The proteomic analysis of the bacterial strains has also revealed significant differences. The comparison of electropherograms of the outer membrane proteome of Escherichia coli BW25113 and its silver-resistant mutant (E. coli AgR), shows several differences, which emerge after prolonged exposure of the wild type strain to $\mathrm{Ag}^{+}$. The protein spots with the most conspicuous alterations between strains were subjected to protein identification using mass spectrometry (Supplementary File S1). All spots selected for analysis are clearly marked in Figure 1. The results showed that some differences did not solely concern a fraction of OMP, probably as a result from the isolation method, but were also recognized as cytosolic or inner membrane molecules with a crucial function, i.e., in the cellular response to oxidative stress, transport of macromolecules, aerobic/anaerobic metabolism, or the maintenance of heavy metal homeostasis. It could be helpful to understand the involvement of proteins from other cellular compartments and their role in the cellular response to the action of silver ions and nanoformulations. The presented 2-DE electropherograms (Figure 1) differ in the number of protein spots or in their optical density (OD). One of the noticeable differences among the electropherograms of E. coli BW25113 and its mutant AgR is connected to flagellin, a subunit protein involved in the formation of bacterial flagella. All proteins, irrespective of their position in the gel, were identified as FliC (spots 1-4, Figure 1). Spots 1 and 2 were not detected in the electropherogram of the wild type E. coli BW25113, while spots 3 and 4 differ in staining intensity. Those detected in the E. coli AgR mutant (especially spot no. 4) exhibit much higher OD that cannot be missed. The scattered location of flagellin could be explained by some modifications of FliC made shortly after the translation process, which have an impact on the molecular mass and pI value of proteins in each spot. In order to obtain additional information about the potential changes of the OMP of E. coli, we decided to expand the analysis by using another strain-E. coli J53, with resistance to $\mathrm{Ag}^{+}$determined by the pMG101 plasmid (Figure 1, Table 2). In the protein profile of E. coli J53, none of the four previously mentioned spots was detected. Further analysis of E. coli BW25113 electropherograms made it possible to identify two changes concerning spots no. 7 and 8 . They were recognized as D-galactose-binding periplasmic protein and superoxide dismutase. OD of both mentioned spots decreases 
in the electropherogram of E. coli BW25113 AgR, strain loss of the OmpC/F porins and derepression of the CusCFBA efflux transporter (Figure 1, Table 2). The spot identified as D-galactose-binding protein seems to have a higher OD in E. coli J53 than the corresponding spot recognized in E. coli BW25113 AgR. Furthermore, the OD value of the aforementioned E. coli J53 spot may be similar in terms of intensity to its wild type counterpart. In the electropherograms of E. coli BW25113 and its AgR mutant, there were two spots identified as aldehyde reductase YahK (no. 9) and protein CutC (no. 10). The aforedescribed spots could not be found in the electropherogram of $E$. coli J53. Other differences between the analyzed electropherograms concern two spots identified as chaperone protein DnaK (no. 5) and isocitrate lyase (no. 6). These spots were detected in both BW25113 strains (wt and $\mathrm{AgR}$ ) with no differences between them. When compared to the protein profile of E. coli J53, they seem to be more distinctive, because the OD of both detected spots notably decreases in relation to the electropherograms of BW25113 strains. The last analyzed change was connected with superoxide dismutase (no. 8). Its intensity in the gels of E. coli AgR and J53 were much lower than the OD of the wild type corresponding spot (E. coli BW25113).

Table 2. Identified proteins from the selected spots of electropherograms of E. coli BW25113, its mutant E. coli BW25113 AgR and E. coli $\mathrm{J} 53$ as reference.

\begin{tabular}{|c|c|c|c|c|}
\hline $\begin{array}{l}\text { Spots In } \\
\text { Figure } 1\end{array}$ & $\begin{array}{l}\text { Identified Proteins } \\
\text { (Encoding Gene) }\end{array}$ & Data & Strains & Function \\
\hline $1-4$ & Flagellin FliC (flyC) & $\begin{array}{l}\mathrm{MW}=51,265 \\
\mathrm{pI}=4.5\end{array}$ & $\begin{array}{l}\text { E. coli BW25113 } \\
\text { AgR only }\end{array}$ & $\begin{array}{l}\text { Subunit protein which polymerizes to form the } \\
\text { filaments of bacterial flagellum (extracellular } \\
\text { component) }\end{array}$ \\
\hline 5 & $\begin{array}{l}\text { Chaperone protein } \\
\text { DnaK }(\text { dnaK) }\end{array}$ & $\begin{array}{l}\mathrm{MW}=69,072 \\
\mathrm{pI}=4.83\end{array}$ & E. coli BW25113 wt & $\begin{array}{l}\text { Essential role in the initiation of phage lambda DNA } \\
\text { replication, involved in chromosomal DNA } \\
\text { replication, participates actively in the response to } \\
\text { hyperosmotic shock }\end{array}$ \\
\hline 6 & $\begin{array}{l}\text { Isocitrate lyase } \\
\text { AceA }(\text { ace } A)\end{array}$ & $\begin{array}{l}\mathrm{MW}=47,782 \\
\mathrm{pI}=5.16\end{array}$ & $\begin{array}{l}\text { E. coli BW25113 } \\
\text { AgR only }\end{array}$ & $\begin{array}{l}\text { Involved in the metabolic adaptation in response to } \\
\text { environmental changes; catalyzes the reversible } \\
\text { formation of succinate and glyoxylate from isocitrate, } \\
\text { a key step of the glyoxylate cycle, which operates as } \\
\text { an anaplerotic route for replenishing the tricarboxylic } \\
\text { acid cycle during growth on fatty acid substrates, } \\
\text { metal binding }\end{array}$ \\
\hline 7 & $\begin{array}{l}\text { D-galactose binding } \\
\text { protein MglB }(m g l B)\end{array}$ & $\begin{array}{l}\mathrm{MW}=35,690 \\
\mathrm{pI}=5.68\end{array}$ & $\begin{array}{l}\text { E. coli BW25113 } \\
\text { AgR only }\end{array}$ & $\begin{array}{l}\text { Protein involved in the active transport of galactose } \\
\text { and glucose. It plays a role in the chemotaxis towards } \\
\text { the two sugars by interacting with the trg } \\
\text { chemoreceptor }\end{array}$ \\
\hline 8 & $\begin{array}{l}\text { Superoxide } \\
\text { dismutase SodF, } \\
\text { SODF, SOD2, } \\
\text { FeSOD I }(\operatorname{sod} F)\end{array}$ & $\begin{array}{l}\mathrm{MW}=21,311 \\
\mathrm{pI}=5.58\end{array}$ & E. coli BW25113 wt & $\begin{array}{l}\text { Destroys superoxide anion radicals which are } \\
\text { normally produced within the cells and which are } \\
\text { toxic to biological systems }\end{array}$ \\
\hline 9 & $\begin{array}{l}\text { Aldehyde reductase } \\
\text { YahK (yahK) }\end{array}$ & $\begin{array}{l}\mathrm{MW}=37,954 \\
\mathrm{pI}=5.80\end{array}$ & E. coli BW25113 wt & Uncharacterized zinc-type alcohol dehydrogenase \\
\hline 10 & $\begin{array}{l}\text { Copper } \\
\text { homeostasis protein } \\
\text { CutC (cutC) }\end{array}$ & $\begin{array}{l}\mathrm{MW}=26,623 \\
\mathrm{pI}=5.75\end{array}$ & $\begin{array}{l}\text { E. coli BW25113 wt } \\
\text { and AgR }\end{array}$ & Control of copper homeostasis, copper ions binding \\
\hline
\end{tabular}



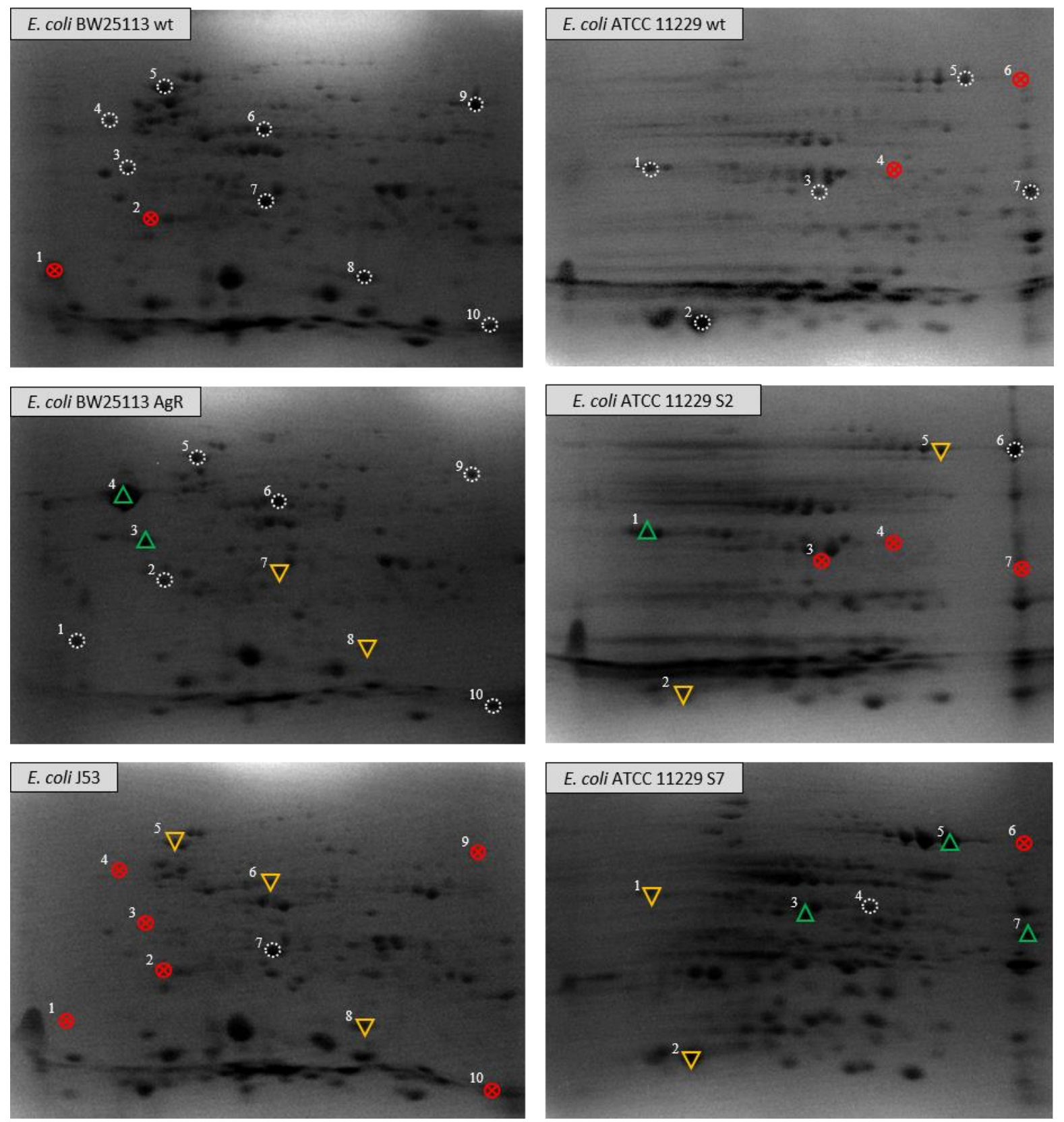

Figure 1. Comparative analysis of two-dimensional electropherograms of Escherichia coli BW25113 and its mutant AgR resistant to silver ions and Escherichia coli ATCC 11229 and its variants: S2 and S7. Legend: reference spot; ${ }^{\otimes}$ selected spots not found in tested sample; $\triangle$ spot with increased optical density; $\quad$ spot with decreased optical density.

The next step of our research was carried out on E. coli ATCC 11229 strains, wild type and both variants (Figure 1). In case of both variants of E. coli ATCC 11229 var. S2 and S7, changes in the outer membrane structures were identified that affected the bacterial susceptibility to the tested nanomaterials and made E. coli cells more resistant to those silver nanoformulations (S2 and S7) [1]. Changes observed in 2-DE electropherograms were distinctive for each of the obtained variants (strain with silver-driven differences) and concerned the absence of selected spots or fluctuations of their OD. As in the case of the previously described E.coli BW25113, the group of the identified spots contained proteins with different localization (cytosol, periplasm, OM) and function.

The concentration of OmpC (no.1) decreased in the case of E. coli ATCC 11229 var. S7 in comparison with its wild type. The opposite situation was observed in the electro- 
pherogram of E. coli ATCC 11229 var. S2, where the OD of the aforementioned spot was much higher. A more significant decrease of OD (regarding the wild type) was observed in another spots (no. 2) of glutaredoxin-4 present on the gels of both variants. The results of the identification showed that spots no. 5 and 6 were actually the same protein-OPPA. It seems that spot no. 6 (present only in the electropherogram of E. coli ATCC 11229 var. S2) is probably a molecule that had undergone some post-transcriptional modifications. In E. coli ATCC 11229 var. S7, OD of spot no. 5 was higher compared to the wild type and S2. Nevertheless, in the case of the second variant mentioned above, the OPPA was represented by two spots; therefore, the final amount of this protein in both variant samples could be the same as in var. S7. Spot no. 3 (Figure 1) was recognized as D-galactose-binding periplasmic protein. The same structure was identified in the electropherograms of E. coli BW25113. The spot occurred only in the wild type and E. coli ATCC 11229 var. S7, but an increase of its OD could be observed only in the gel of the variant (Figure 1). The same situation was observed in the case of protein no. 7 , identified as a thiosulfate-binding protein. The last analyzed difference between E. coli ATCC 11229 strains concerned spot no. 4, recognized as malate dehydrogenase (found only in E. coli ATCC 11229 var. S7). A correlation was discovered between the genetic changes and proteins detected in 2-DE, and referred to: (i) the subunit protein, which polymerizes to form the filaments of bacterial flagella (extracellular component) - fliC (conservative mutation) in E. coli BW25113 AgR; (ii) the active transport of galactose and glucose; (iii) chemotaxis towards the two sugars by interacting with the trg chemoreceptor- $m g l B$ (non-conservative mutation) in E. coli ATCC 11229 var. S7 (Table 3). Moreover, conservative mutation was detected in a component of the oligopeptide permease, a binding protein-dependent transport system, involved in the binding of peptides up to five amino acids long with high affinity to the-appA gene in E. coli ATCC 11229 var. S2 and S7 (Table 3). It is worth emphasizing that conservative mutation was also found in rpoD-initiation factors that promote the attachment of RNA polymerase to specific initiation sites and then its release. This factor is the primary sigma factor during exponential growth. Preferentially transcribed genes are associated with fast growth and they include ribosomal operons, other protein-synthesis related genes, rRNAand tRNA-encoding genes, and $\operatorname{prfB}$ (directing to the termination of translation in response to the peptide chain termination codons UGA and UAA).

Table 3. Identified proteins from the selected spots of electropherograms of E. coli ATCC 11229 and its variants E. coli ATCC 11229 var. S2 and S7.

\begin{tabular}{|c|c|c|c|c|}
\hline $\begin{array}{l}\text { Spots in } \\
\text { Figure } 1\end{array}$ & $\begin{array}{l}\text { Identified Protein } \\
\text { (Encoding Gene) }\end{array}$ & Data & Strains & $\begin{array}{l}\text { Function } \\
\text { (https://www.uniprot.org/ accessed on } \\
12 \text { November 2020) }\end{array}$ \\
\hline 1 & OmpC (ompC) & $\begin{array}{l}\mathrm{M}=40,343 \\
\mathrm{pI}=4.58\end{array}$ & $\begin{array}{l}\text { E. coli ATCC } 11229 \\
\text { wt only }\end{array}$ & $\begin{array}{l}\text { Forms pores that allow passive diffusion of small } \\
\text { molecules across the outer membrane. } \\
\text { Microbial infection: supports colicin E5 entry in the } \\
\text { absence of its major receptor OmpF, A mixed } \\
\text { OmpC-OmpF heterotrimer is the outer membrane } \\
\text { receptor for toxin CdiA-EC536; polymorphisms in } \\
\text { extracellular loops } 4 \text { and } 5 \text { of OmpC confer susceptibility } \\
\text { to CdiA-EC536-mediated toxicity. }\end{array}$ \\
\hline 2 & $\begin{array}{l}\text { Glutaredoxin-4 } \\
\text { GrxD }(g r x D)\end{array}$ & $\begin{array}{l}\mathrm{M}=13,044 \\
\mathrm{pI}=4.75\end{array}$ & $\begin{array}{l}\text { E. coli ATCC } 11229 \\
\text { wt only }\end{array}$ & $\begin{array}{l}\text { Monothiol glutaredoxin involved in the biogenesis of } \\
\text { iron-sulfur clusters. }\end{array}$ \\
\hline 3 & $\begin{array}{l}\text { D-galactose- } \\
\text { binding periplasmic } \\
\text { protein } \operatorname{MglB}(m g l B)\end{array}$ & $\begin{array}{l}\mathrm{M}=35,690 \\
\mathrm{pI}=5.68\end{array}$ & $\begin{array}{l}\text { E. coli ATCC } 11229 \\
\text { var. S7 }\end{array}$ & $\begin{array}{l}\text { Protein involved in the active transport of galactose and } \\
\text { glucose. It plays a role in the chemotaxis towards the two } \\
\text { sugars by interacting with the trg chemoreceptor. }\end{array}$ \\
\hline 4 & $\begin{array}{l}\text { Malate } \\
\text { dehydrogenase } \\
\text { Mgh }(m d h)\end{array}$ & $\begin{array}{l}\mathrm{M}=32,317 \\
\mathrm{pI}=5.61\end{array}$ & $\begin{array}{l}\text { E. coli ATCC } 11229 \\
\text { var. S7 }\end{array}$ & $\begin{array}{l}\text { Catalyzes the reversible oxidation of malate to } \\
\text { oxaloacetate. }\end{array}$ \\
\hline
\end{tabular}


Table 3. Cont.

\begin{tabular}{lllll}
\hline $\begin{array}{l}\text { Spots in } \\
\text { Figure } 1\end{array}$ & $\begin{array}{l}\text { Identified Protein } \\
\text { (Encoding Gene) }\end{array}$ & Data & Strains & $\begin{array}{l}\text { Function } \\
\text { (https://www.uniprot.org/ accessed on } \\
\text { 12 November 2020) }\end{array}$ \\
\hline 5-6 & $\begin{array}{l}\text { Periplasmic } \\
\text { oligopeptide- } \\
\text { binding protein } \\
\text { OppA }(\text { opp } A)\end{array}$ & $\begin{array}{l}\mathrm{M}=60,977, \\
\mathrm{pI}=6.05\end{array}$ & $\begin{array}{l}\text { E. coli ATCC } 11229 \\
\text { var. S2 and S7 }\end{array}$ & $\begin{array}{l}\text { Component of the oligopeptide permease, a binding } \\
\text { protein-dependent transport system, it binds peptides up } \\
\text { to five amino acids long with high affinity. }\end{array}$ \\
\hline $\begin{array}{l}\text { Thiosulfate- } \\
\text { binding protein } \\
\text { CysP }(c y s P)\end{array}$ & $\begin{array}{l}\mathrm{M}=37,591, \\
\mathrm{PI}=6.81\end{array}$ & $\begin{array}{l}\text { E. coli ATCC } 11229 \\
\text { wt only }\end{array}$ & $\begin{array}{l}\text { Part of the ABC transporter complex CysAWTP involved } \\
\text { in sulfate/thiosulfate import. This protein specifically } \\
\text { binds thiosulfate and is involved in its transmembrane } \\
\text { transport. }\end{array}$ \\
\hline
\end{tabular}

MW [Da]—molecular mass, pI-isoelectric point.

\section{Discussion}

Much effort has been made to explain the molecular mode of the antibacterial action of silver nanomaterials, and the observations made are inconsistent. On the basis of published results, it can be speculated that the antibacterial mechanism of action strongly depends on the physical and chemical properties of the used silver formulation probably such as size, shape, charge, composition, surface $[1,2,4,9,10]$. Moreover, after repeated, prolonged treatment with $\mathrm{Ag}^{+}$or various types of silver nanoparticles, phenotypic as well as genetic changes in the bacterial cell have been observed $[1,4,8]$. Observation of the bacterial structures indicated the strong interaction of SNF with the cell wall [1,4]. Wen-Ru Li et al. [14] have shown that silver nanoparticles (with different sizes, $5 \mathrm{~nm}, 20 \mathrm{~nm}$, respectively) can cause severe damage to bacteria cell, but they have not made a differentiation between silver ions and silver nanoparticles. Yan et al. [15] have confirmed that both tested silver forms (ions and nanoparticles) can penetrate into the bacterial cell. They have investigated the molecular mechanisms of the antimicrobial activity of silver nanoparticles in Pseudomonas aeruginosa using the proteomic approach and have suggested that the interference with cell-membrane functions and generation of intracellular reactive oxygen species (ROS) are the main pathways for the antibacterial activity of silver nanoparticles and silver ions. The differences between antibacterial mode of action in case of the two kinds of silver $\mathrm{Ag}^{+}$and silver nanoparticles) have also been indicated by the others and genotoxicity consequences have been initially performed $[4,8,14]$. Anuj et al. [16] have suggested that nanosilver can modify the membrane integrity of $E$. coli in addition to the obstruction of the activity of efflux pumps. Silver nanoparticles may be localized inside the $E$. coli cell membrane or they may completely separate the cell membrane causing membrane damage [16]. Our latest results suggest that multiple OMP proteins are responsible for uptake of silver ions and silver nanoformulations [4]. As we pinpointed, SNF were more efficacious against all tested bacterial strains than silver ions, and this was confirmed with computational methods: weaker interactions of $\mathrm{Ag}^{0}$ with amino acids of inner layers of both investigated proteins allow $\mathrm{Ag}^{0}$ to "slide" inside the cell more effectively-with a lower energy barrier in comparison to $\mathrm{Ag}^{+}$[4]. However, according to Lok et al. [17] mode of action of silver ions was similar to spherical nano-Ag (average diameter $9.3 \mathrm{~nm}$ ), but nano-Ag was found as efficacy at lower concentration than silver ions. Using the proteomic approach, we showed the decrease of OmpC protein expression in E. coli ATCC 11229 after exposure to SNF S7, and its increase after the sample treatment with S2 silver (this was observed only in E. coli ATCC 11229, cf. Figure 1, Table 3). In contrast to E. coli AgR strains carrying mutations after silver ions treatment [8], no changes in $\mathrm{ompR}$ was identified in case of E. coli ATCC var. S2. However, some conservative mutations in ompC and non-conservative mutations in $o m p F$ were separately noticed. Observed mutation in the ompC gene could have influenced the $о т p C$ gene overexpression and uptake the biocides to bacteria cell. In the cusS gene, different mutation was also noticed by us in E. coli ATCC var. S2 than in 
E. coli AgR obtained by Randall et al. [8]: Thr81Ala, Asn117Asp, Thr118Ser in contrast to Ile213Ser, Ala312Glu and Arg377His, respectively.

Anuj et al. [16] have postulated that O-antigen (part of the LPS) in the E. coli strain may also be responsible for the interaction of silver nanoparticles with bacterial cell, so strains with mutations in this part of cell structure may be less or more sensitive to silver nanoformulations. Besides O-antigen, flagella is considered as part of a bacterial structure responsible for increase to silver nanoparticles resistance. Wen-Ru Li et al. [14] have observed that the flagella of the E. coli strain have been damaged or even eliminated, finally causing impairment of the cell movement. The upregulation of the FliC protein has also been observed in the bacterial cell after treatment with silver ions and nanoparticles by Yan et al [15]. According to Panáček et al. [10], the flagella of E. coli cause aggregation of silver nanoparticles without any genetic changes. In our studies, OD of FliC spot increased after treatment with $\mathrm{Ag}^{+}$in case of $E$. coli BW25113. We identified the conservative mutations in the regulatory genes of $f l i C$, flagellar basal-body P-ring formation protein (flgA) and a regulator of cell motility (fliZ) in E. coli ATCC var. S2 strain (Supplementary Materials Table S2). Moreover, the upregulation of $f l i C$ in the proteinogram of the endogenously silver-resistant strain (E. coli AgR) was observed by us, while the model of an exogenously silver-resistant strain, E. coli J53, exhibited downregulation of this protein (Figure 1). It is interesting that E. coli ATCC 11229 strain and its variants (S2 and S7), besides of numerous mutations indicated in E. coli ATCC 11229 var. S2, still stay sensitive to antibiotics, while other Gram-negative (such as E. coli, Klebsiella pneumoniae or Enterobacter cloacae) and Grampositive bacteria (Staphylococcus aureus) bacteria strains stay the same or become resistant to antibiotics [4].

The consequences of the phenotypic (including membrane rearrangements) and genetic changes may alter the sensitivity of bacteria to biocides and antibiotics (depending on the properties of the applied silver type) after repeated treatment with silver ions or nanoformulations $[1,16]$. The implications of those mutations, and how those mutations are correlated with the silver nanoformulation treatment, is not clear now. The importance of the observed mutations and their correlation with the silver nanoformulations need more explanation.

\section{Materials and Methods}

\subsection{Materials}

\subsubsection{Strains}

The following bacteria strains were subjected to proteomic and genetic analysis to assess changes induced by the silver treatment: E. coli BW25113 wt (wild type) and its mutant E. coli BW25113 AgR, E. coli J53, E. coli ATCC $11229 \mathrm{wt}$ (wild type) and its variants: E. coli ATCC 11229 var. S2, and E. coli ATCC 11229 var. S7 (they are described in details in Table 4) $[1,8,18,19]$. They were store in $-70{ }^{\circ} \mathrm{C}$ (Revco) after selection as described previously $[1,8]$. We compared the proteome changes in all of the tested strains, additionally one of the strains: E. coli ATCC 11229 var. S2 was selected for a detailed genetic analysis according to the number of the selected mutations (general genetic information was mentioned in our previous study [1]). It is worth emphasizing that in this case attempts to obtain variants of E. coli BW25113 resistant to S2 and S7 failed, as this strain has remained sensitive to those silver nanoformulations samples during our experiment. 
Table 4. Bacteria strains used in this work.

\begin{tabular}{|c|c|c|c|}
\hline \multicolumn{2}{|l|}{ Bacteria Strains } & \multirow[b]{2}{*}{ Genome Analysis } & \multirow{2}{*}{$\begin{array}{l}\text { Proteome } \\
\text { Analysis }\end{array}$} \\
\hline $\begin{array}{l}\text { Wild Type Strains and Its } \\
\text { Variants }\end{array}$ & Description & & \\
\hline E. coli BW25113 wt & Wild type strain & [8] (Reference strain) & This work \\
\hline $\begin{array}{l}\text { E. coli BW25113 AgR } \\
\text { (full name: } \\
\text { E. coli BW25113 } \\
\text { ompRG596AcusSG1130A) }\end{array}$ & $\begin{array}{l}\text { Variant of E. coli BW25113 wt resistant to silver ions } \\
\left(\mathrm{Ag}^{+}\right) \text {due to mutations, in ompR and cusS, } \\
\text { respectively, conferred loss of the OmpC/F porins } \\
\text { and derepression of the CusCFBA efflux transporter }\end{array}$ & [8] & This work \\
\hline E. coli J53 & $\begin{array}{l}\text { Model organism with pMG101 plasmid encoding sil } \\
\text { genes determining the resistance to silver ions }\end{array}$ & $\begin{array}{l}\text { [8] (Reference strain with } \\
\text { exogenous resistance to } \\
\text { silver ions) }\end{array}$ & This work \\
\hline E. coli ATCC 11229 wt & $\begin{array}{l}\text { Wild type strain treated with different silver (ions } \\
\text { and nanoformulations) }\end{array}$ & $\begin{array}{l}\text { This work (reference } \\
\text { strain) }\end{array}$ & This work \\
\hline E. coli ATCC 11229 var. S2 & $\begin{array}{l}\text { Variant of E. coli ATCC } 11229 \text { wt with decreased } \\
\text { sensitivity to SNF S2 * (after S2 treatment) }\end{array}$ & This work & This work \\
\hline E. coli ATCC 11229 var. S7 & $\begin{array}{l}\text { Variant of E. coli ATCC } 11229 \text { wt with decreased } \\
\text { sensitivity to SNF S7 * (after S7 treatment) }\end{array}$ & $\begin{array}{l}\text { Small number of } \\
\text { mutations analyzed in } \\
\text { previous work [1] }\end{array}$ & This work \\
\hline
\end{tabular}

* Legend: silver nanoformulation signed as S2 refers to titanium dioxide doped with silver nanoparticles, while silver nanoformulation signed as $\mathrm{S} 7$ refers to water colloid of silver $[18,19]$.

\subsubsection{Reagents}

Genomic DNA Isolation

Culture medium - Lysogeny Broth Lennox (LB) (Sigma-Aldrich, Saint Louis, MO, USA); Genomic Mini Kit (A\&A Biotechnology, Gdańsk, Poland).

\section{OMP Isolation}

Culture medium—Lysogeny Broth Lennox (LB) (Sigma-Aldrich, Saint Louis, USA); buffer A: $1 \mathrm{M}$ sodium acetate (POCH), $1 \mathrm{mM} \beta$-mercaptoethanol (Merck, Darmstadt, Germany), ultra-pure water; buffer B: 5\% (w/v) Zwittergent Z 3-14 ${ }^{\circledR}$ (Calbiochem, San Diego, CA, USA), $0.5 \mathrm{M} \mathrm{CaCl}_{2}$ (POCH, Gliwice, Poland), ultra-pure water; buffer C: $50 \mathrm{mM}$ TrizmaBase (Sigma-Aldrich, Saint Louis, USA), 0.05\% (w/v) Zwittergent Z 3-14 ${ }^{\circledR}$ (Calbiochem, San Diego, USA), 10 mM EDTA (Sigma-Aldrich, Saint Louis, USA) (pH 8.0); 96\% (v/v) ethanol (Merck, Darmstadt, Germany), ultra-pure water; BCA Protein Assay Kit (Thermo Scientific, Waltham, MA, USA).

Two-Dimensional Gel Electrophoresis

Immobilized gradient IPG strips ( $\mathrm{pH} 4-7,7 \mathrm{~cm}$ ) (Bio-Rad, Hercules, CA, USA), ReadyPrep ${ }^{\text {TM }}$ 2-D Cleanup Kit (Bio-Rad, CA, USA), Mini-PROTEAN Tetra Cell System (Bio-Rad), agarose (Bio-Rad, CA, USA), Coomassie Brilliant Blue (Bio-Rad, CA, USA), polyacrylamide gels: $30 \%$ acrylamide/bis-acrylamide solution (Bio-Shop, Burlington, Canada), TRIS (Sigma-Aldrich, Saint Louis, USA), $\mathrm{HCl}$ (POCH, Gliwice, Poland), 10\% ( $w / v$ ) sodium dodecyl sulfate (Sigma-Aldrich, Saint Louis, USA), 10\% (w/v) ammonium persulfate (BioShop, Burlington, ON, Canada), TEMED (Bio-Shop, Burlington, Canada), ultra-pure water.

\section{In-Gel Protein Digestion and MS Protein Identification}

Ultra-pure water and LC-MS grade solvents were used for protein digestion and MS experiments. De-staining buffer: $100 \mathrm{mM} \mathrm{NH}_{4} \mathrm{HCO}_{3}$ (Merck, Darmstadt, Germany), acetonitrile (Merck, Darmstadt, Germany), 1:1 v/v; reduction buffer: $10 \mathrm{mM}$ dithiothreitol (Sigma-Aldrich, Saint Louis, USA) in $100 \mathrm{mM} \mathrm{NH}_{4} \mathrm{HCO}_{3}$ (Merck, Darmstadt, Germany), alkylation buffer: $55 \mathrm{mM}$ iodoacetamide (Sigma-Aldrich, Saint Louis, USA) in $100 \mathrm{mM}$ $\mathrm{NH}_{4} \mathrm{HCO}_{3}$ (Merck, Darmstadt, Germany), trypsin solution: $13 \mathrm{ng} / \mu \mathrm{L}$ trypsin (Promega, 
Madison, WI, USA) in $10 \mathrm{mM} \mathrm{NH}_{4} \mathrm{HCO}_{3}$ (Merck, Darmstadt, Germany) containing $10 \%$ $(v / v)$ acetonitrile (Merck, Darmstadt, Germany); Pierce C18 pipette tips (Thermo-Scientific, Waltham, USA), elution buffer: $10 \mathrm{mg} / \mathrm{mL}$ of $\alpha$-cyano-4-hydroxycinnamic acid (Bruker, Billerica, MA, USA) in acetonitrile: 0.1\% TFA (Merck, Darmstadt, Germany) in $\mathrm{H}_{2} \mathrm{O}$ 7:3 v/v.

\subsection{Methods}

\subsubsection{Genome Analysis}

Genomic DNA of the bacteria was isolated using Genomic Mini Kit ( $2 \mathrm{~mL}$ of overnight bacterial cultures in LB medium) (Biomaxima, Lublin, Poland). The purity and concentration of the product was measured with a nano spectrophotometer (Implen). Genomic libraries were prepared using NEBNext DNA Library Prep Master Mix Set for Illumina and sequencing was performed in Genomed (Warsaw, Poland) using Illumina MiSeq. NGS reads were preprocessed with Cutadapt 1.9.1 [20], assembled with spades [21], and contigs were rearranged with progressive Mauve in Mauve 2.4.0 [22,23], using the genome of E. coli K-12 substr. MG1655 (NC_000913.3) as reference. A mutations list was generated with snippy [24]. Membrane related genes containing mutations were extracted from the list on the basis of the results obtained from the UniProt KB database (keywords: flagellum (KW-0975), bacterial flagellum biogenesis (KW-1005), cell adhesion (KW-0130), exopolysaccharide synthesis (KW-0270), fimbrium biogenesis (KW-1029), fimbrium structural protein (KW-0281), flagellar rotation (KW-0283), lipopolysaccharide biosynthesis (KW-0448), membrane (KW-0472), and the organism Escherichia coli (strain K12) (83333)) and from the current E. coli Membranome database [25]. Non-synonymous mutations in those genes were assessed in two ways: by assigning the BLOSUM62 score [11,12], and using an analysis of the mutfunc mutation database [26]. Non-conservative mutations were selected as those with a negative BLOSUM62 score or were proposed directly by mutfunc. NGS reads are available in the NCBI SRA database (SRR9733699, SRR9733700, SRR9733697), and the assembled genomes in the NCBI Nucleotide database (VLTC00000000, VLTB00000000, VLTA00000000, and ASRI00000000).

\subsubsection{Proteome Analysis}

OMP isolation was performed according to the Murphy and Bartos procedure with minor modifications $[27,28]$. Overnight culture of bacteria (LB medium, $37^{\circ} \mathrm{C}, 18-24 \mathrm{~h}$ ) was harvested $\left(1500 \mathrm{~g}, 4^{\circ} \mathrm{C}, 20 \mathrm{~min}\right)$ and suspended in $1.25 \mathrm{~mL}$ of buffer $\mathrm{A}$. $11.25 \mathrm{~mL}$ of buffer B was added and the mixture was stirred $(\mathrm{rt}, 1 \mathrm{~h}) .3 .13 \mathrm{~mL}$ of cold ethanol was added slowly in order to precipitate the nucleic acids and the mixture was centrifuged $\left(17,000 \times g, 4^{\circ} \mathrm{C}\right.$, $10 \mathrm{~min})$. Then $46.75 \mathrm{~mL}$ of cold ethanol was added to the supernatant $\left(17,000 \mathrm{~g}, 4^{\circ} \mathrm{C}, 20 \mathrm{~min}\right)$. The pellet was dried, resuspended in $2.5 \mathrm{~mL}$ of buffer $\mathrm{C}$ and stirred $(\mathrm{rt}, 1 \mathrm{~h})$. The solution was incubated at $4{ }^{\circ} \mathrm{C}$ overnight. OMP remained in the soluble fraction of the buffer and the insoluble material was removed by centrifugation $\left(12,000 \times g, 4^{\circ} \mathrm{C}, 10 \mathrm{~min}\right)$. BCA Protein Assay Kit was used for the total protein concentration measurement. ReadyPrep 2-D clean up kit (Bio-Rad) was used for sample preparation. Isoelectric focusing (IEF) was performed by a stepwise increase of voltage as follows: $250 \mathrm{~V}, 20 \mathrm{~min} ; 4000 \mathrm{~V}, 120 \mathrm{~min}$ (linear) and $4000 \mathrm{~V}$ (rapid), until the total volt-hours reached $14 \mathrm{kVh}$. IPG strips were loaded onto the top of gel slabs using $0.5 \%$ agarose in the running buffer. Electrophoresis was carried out at $4{ }^{\circ} \mathrm{C}$ with constant power current $(1 \mathrm{~W})$ until the dye front reached the bottom of the slab $[29,30]$. Protein spots were visualized with Coomassie Brilliant Blue staining. PDQuest software (Bio-Rad) was used for protein spot pattern analysis. Protein spots selected for the mass spectrometry analysis were subjected to the in-gel tryptic digestion according to Shevchenko et al. [31] Mass spectrometry analysis using the MALDI TOF ultrafleXtreme instrument (Bruker Daltonics) was performed afterwards. The peptides were eluted directly on a MALDI plate using a solution of $\alpha$-cyano-4-hydroxycinnamic acid as the matrix. Protein identification was accomplished with a bioinformatics platform (ProteinScape, Bruker Daltonics) and MASCOT (Matrix Science) as a search engine in protein sequence databases (NCBI, SwissProt). 


\section{Conclusions}

Both E. coli wild types ATCC 11229 and E. coli BW25113 were treated with silver ions and silver nanoformulations (SNF), but E. coli ATCC 11229 has changed sensitivity mainly after treatment with SNF S2, the change in sensitivity was less for SNF S7, and no change of sensitivity was observed for $\mathrm{Ag}^{+}$, while E. coli BW25113 has not changed after exposure to SNF S2 and SNF S7, but showed derivations after silver ions treatment. Silver nanoformulations exert a selective pressure on bacterial cells, causing both conservative and non-conservative mutations, and/or phenotypical changes in different way than silver ions. A genetic analysis by the whole-genome sequencing provided a better understanding of the interactions between silver nanoformulations and E. coli strains. The following genes were selected with mutfunc and analyzed by Blosum 62 as those with conservative and non-conservative mutations: encoding proteins located in the outer membrane (including $\mathrm{OmpC}, \mathrm{OmpF}, \mathrm{OmpG}$, and $\mathrm{OmpN}$ ) and their regulators, genes related to $\mathrm{OM}$ and other outer membrane structures, such as flagellum, fimbria, LPS, or exopolysaccharide. Using the proteomic approach with protein isolation and 2-DE experiment, we showed that the optical density changed for some protein spots in 2D electropherograms, such as OmpC or FliC, isocitrate lyase AceA, chaperone protein DnaK, D-galactose binding protein $\mathrm{MglB}$, thiosulfate-binding protein CysP, malate dehydrogenase Mgh, glutaredoxin- 4 GrxD, periplasmic oligopeptide-binding protein OppA, and $\mathrm{OmpC}$, depending on the silver form used for treatment. The molecular mechanism of the antibacterial activity of silver and molecular changes in bacterial cells strongly depend on the physical and chemical properties of the tested SNF form. At this time, it is difficult to conclude what physicochemical properties determine antibacterial cytotoxicity and genotoxicity. Therefore, the mode of action of antibacterial SNF is apparently much more complex and the phenomenon of bacterial resistance to silver requires further and deeper studies.

Supplementary Materials: The following are available online at https: / www.mdpi.com/article / 10.3390 / pathogens10070817/s1, Table S1. Genes encoding outer membrane proteins selected with mutfunc and list of conservative and non-conservative mutations selected with BLOSUM62; Table S2. The other part of genes encoding proteins connected with outer membrane (OM), flagellum, fimbria, lipopolysaccharide (LPS), exopolysaccharide selected with mutfunc and list of conservative mutations selected with BLOSUM62; Table S3. Regulatory genes selected with EcoCyc Database and list of conservative and non-conservative mutations selected with BLOSUM62. File S1: Mass spectrometry results of each spot for E. coli BW25113 and E. coli ATCC 11229.

Author Contributions: A.K.: conceptualization, resources, genetic investigation, genome data analysis, proteome data analysis, writing, drawing conclusions; M.S.: proteome investigation, partial conceptualization, including protein isolation and 2-DE electrophoresis, proteome data analysis, writing; M.W.: genome analysis, writing; B.D.: protein isolation and 2-DE electrophoresis supervision, writing; K.K., E.K.: MALDI sequencing and identification of proteins, supervision, writing; J.R.: supervision, writing-review and editing; G.B.-P.: supervision, resources, writing-review and editing. All authors have read and agreed to the published version of the manuscript.

Funding: This work was partially supported by the National Science Centre (grant number 2017/01/ X/NZ1/00765); and by a special-purpose grant from the Ministry of Science and Higher Education, for conducting research, development work, and tasks related to the development of young scientists and doctoral participants (grant number 0420/2559/18). Publication of this article was financially supported by the Excellence Initiative-Research University (IDUB) program for the University of Wroclaw.

Acknowledgments: The authors wish to thank A. O'Neill and Ch. Randall (Faculty of Biological Sciences School of Molecular and Cellular Biology University of Leeds, United Kingdom) for providing strains for research (E. coli BW25113 wt, E. coli BW25113 AgR, and E. coli J53). Access permission to work with mutants: $01.2-147 / 2017$.

Conflicts of Interest: The authors declare no conflict of interest. 


\section{References}

1. Kędziora, A.; Wernecki, M.; Korzekwa, K.; Speruda, M.; Gerasymchuk, Y.; Łukowiak, A.; Bugla-Płoskońska, G. Consequences of Long-Term Bacteria's Exposure To Silver Nanoformulations With Different PhysicoChemical Properties. Int. J. Nanomed. 2020, 15, 199-213. [CrossRef] [PubMed]

2. Kędziora, A.; Speruda, M.; Krzyżewska, E.; Rybka, J.; Łukowiak, A.; Bugla-Płoskońska, G. Similarities and Differences between Silver Ions and Silver in Nanoforms as Antibacterial Agents. Int. J. Mol. Sci. 2018, 19, 444. [CrossRef] [PubMed]

3. Pareek, V.; Gupta, R.; Panwar, J. Do physico-chemical properties of silver nanoparticles decide their interaction with biological media and bactericidal action? Mater. Sci. Eng. C Mater. Biol. Appl. 2018, 90, 739-749. [CrossRef]

4. Kędziora, A.; Wieczorek, R.; Speruda, M.; Matolínová, I.; Goszczyñski, T.M.; Litwin, I.; Matolín, V.; Bugla-łoskonska, G. Comparison of Antibacterial Mode of Action of Silver Ions and Silver Nanoformulations With Different Physico-Chemical Properties: Experimental and Computational Studies. Front. Microbiol. 2021, 12, 659614. [CrossRef]

5. Liu, Y.F.; Yan, J.J.; Lei, H.Y. Loss of outer membrane protein C in Escherichia coli contributes to both antibiotic resistance and escaping antibody-dependent bactericidal activity. Infect. Immun. 2012, 80, 1815-1822. [CrossRef] [PubMed]

6. Li, X.Z.; Nikaido, H.; Williams, K.E. Silver resistant mutants of Escherichia coli display active efflux of Ag+ and are deficient in porins. J. Bacteriol. 1997, 179, 6127-6132. [CrossRef]

7. Radzig, M.; Nadtochenko, V.; Koksharova, O.; Kiwi, J.; Lipasova, V.; Khmel, I. Antibacterial effects of silver nanoparticles on gram negative bacteria: Influence on the growth and biofilms, mechanisms of action. Colloids Surf. B Biointerfaces 2013, 102, 300-306. [CrossRef] [PubMed]

8. Randall, C.; Gupta, A.; Jackson, N.; Busse, D.; O’Neill, A.J. Silver resistance in Gram-negative bacteria: A dissection of endogenous and exogenous mechanisms. J. Antimicrob. Chemother. 2015, 70, 1037-1046. [CrossRef]

9. Ansari, M.A.; Khan, H.M.; Khan, A.A.; Ahmad, M.K.; Mahdi, A.A.; Pal, R.; Cameotra, S.S. Interaction of silver nanoparticles with Escherichia coli and their cell envelope biomolecules. J. Basic Microbiol. 2014, 54, 905-915. [CrossRef]

10. Panáček, A.; Kvítek, L.; Smékalová, M.; Večeřová, R.; Kolář, M.; Röderová, M.; Dyčka, F.; Šebela, M.; Prucek, R.; Tomanec, O.; et al. Bacterial resistance to silver nanoparticles and how to overcome it. Nat. Nanotechnol. 2018, 13, 65-71. [CrossRef]

11. Henikoff, S.; Henikoff, J.G. Amino acid substitution matrices from protein blocks. Proc. Natl. Acad. Sci. USA 1992, 89, 10915-10919. [CrossRef] [PubMed]

12. Lee, H.; Popodi, E.; Tang, H.; Foster, P.L. Rate and molecular spectrum of spontaneous mutations in the bacterium Escherichia coli as determined by whole-genome sequencing. Proc. Natl. Acad. Sci. USA 2012, 109, E2774-E2783. [CrossRef]

13. Nazir, R.; Rehman, S.; Nisa, M.; Baba, U.A. Exploring Bacterial Diversity: From Cell to Sequence; Freshwater Microbiology Elsevier Inc.: London, UK, 2019; ISBN 978-0-12-817495-1. [CrossRef]

14. Li, W.; Sun, T.; Zhou, S.; Ma, Y.; Shi, Q.; Xie, X.; Huang, X. A comparative analysis of antibacterial activity, dynamics, and effects of silver ions and silver nanoparticles against four bacterial strains. Int. Biodeterior. Biodegrad. 2017, 123, 304-310. [CrossRef]

15. Yan, X.; He, B.; Liu, L.; Qu, G.; Shi, J.; Hu, L.; Jiang, G. Antibacterial mechanism of silver nanoparticles in Pseudomonas aeruginosa: Proteomics approach. Metallomics 2018, 10, 557. [CrossRef] [PubMed]

16. Anuj, S.A.; Gajera, H.; Hirpara, D.G.; Golakiya, B.A. Bacterial membrane destabilization with cationic particles of nano-silver to combat efflux-mediated antibiotic resistance in Gram-negative bacteria. Life Sci. 2019, 230, 178-187. [CrossRef]

17. Lok, C.; Ho, C.; Chen, R.; He, Q.I.; Yu, W.; Sun, H.; Tam, P.K.; Chiu, J.; Che, C. Proteomic Analysis of the Mode of Antibacterial Action of Silver Nanoparticles. Proteome Res. 2006, 5, 916-924. [CrossRef] [PubMed]

18. Kedziora, A.; Korzekwa, K.; Strek, W.; Pawlak, A.; Doroszkiewicz, W.; Bugla-Ploskonska, G. Silver Nanofilms as a Therapeutic Agent for Killing Escherichia coli and Certain ESKAPE Pathogens. Curr. Microbiol. 2016, 73, 139-147. [CrossRef] [PubMed]

19. Kedziora, A.; Strek, W.; Kȩpiński, L.; Bugla-Ploskonska, G.; Doroszkiewicz, W. Synthesis and antibacterial activity of novel titanium dioxide doped with silver. J. Sol-Gel Sci. Technol. 2012, 62, 79-86. [CrossRef]

20. Martin, M. Cutadapt removes adapter sequences from high-throughput sequencing reads. EMB Net. J. 2011, 17, 10. [CrossRef]

21. Bankevich, A.; Nurk, S.; Antipov, D.; Gurevich, A.; Dvorkin, M.; Kulikov, A.; Lesin, V.M.; Nikolenko, S.; Pham, S.; Prjibelski, A.D.; et al. SPAdes: A new genome assembly algorithm and its applications to single-cell sequencing. J. Comput. Biol. 2012, 19, 455-477. [CrossRef]

22. Darling, A.C.E.; Mau, B.; Blattner, F.R.; Perna, N.T. Mauve: Multiple alignment of conserved genomic sequence with rearrangements. Genome Res. 2004, 14, 1394-1403. [CrossRef] [PubMed]

23. Darling, A.E.; Mau, B.; Perna, N.T. Progressive Mauve: Multiple genome alignment with gene gain, loss and rearrangement. PLoS ONE 2010, 5, e11147. [CrossRef]

24. Seemann, T. Prokka: Rapid prokaryotic genome annotation. Bioinformatics 2014, 30, 2068-2069. [CrossRef] [PubMed]

25. Sueki, A.; Stein, F.; Savitski, M.M.; Selkrig, J.; Typas, A. Systematic Localization of Escherichia coli Membrane Proteins. Msystems 2020, 5, 2. [CrossRef] [PubMed]

26. Wagih, O.; Galardini, M.; Busby, B.P.; Memon, D.; Typas, A.; Beltrao, P. A resource of variant effect predictions of single nucleotide variants in model organisms. Mol. Syst. Biol. 2018, 14, e8430. [CrossRef]

27. Murphy, T.F.; Bartos, L.C. Surface-exposed and antigenically conserved determinants of outer membrane proteins of Branhamella catarrhalis. Infect. Immun. 1989, 57, 2938-2941. [CrossRef] 
28. Bugla-Płoskońska, G.; Korzeniowska-Kowal, A.; Guz-Regner, K. Reptiles as a source of Salmonella O48-clinically important bacteria for children: The relationship between resistance to normal cord serum and outer membrane protein patterns. Microb. Ecol. 2011, 61, 41-51. [CrossRef]

29. Farrell, P.H. High resolution two-dimensional electrophoresis of proteins. J. Biol. Chem. 1975, 250, 4007-4021. [CrossRef]

30. Bednarz-Misa, I.; Serek, P.; Dudek, B.; Pawlak, A.; Bugla-Płoskońska, G.; Gamian, A. Application of zwitterionic detergent to the solubilization of Klebsiella pneumoniae outer membrane proteins for two-dimensional gel electrophoresis. J. Microbiol. Methods 2014, 107, 74-79. [CrossRef]

31. Shevchenko, A.; Tomas, H.; Havlis, J.; Olsen, J.V.; Mann, M.J. In-gel digestion for mass spectrometric characterization of proteins and proteomes. Nat. Protoc. 2006, 1, 2856-2860. [CrossRef] 